http:/ /dx.doi.org/10.1590/0104-07072017003100015

\title{
THE EXPERIENCES OF THE REORIENTATION PROGRAM FOR PROFESSIONAL TRAINING IN NURSING - ADVANCES AND CHALLENGES
}

\author{
Laura Cavalcanti de Farias Brehmer', Flávia Regina Souza Ramos ${ }^{2}$
}

\author{
${ }^{1}$ Ph.D. in Nursing. Professor, Departamento de Enfermagem, Universidade Federal de Santa Catarina (UFSC). Florianópolis, Santa \\ Catarina, Brasil. E-mail: laura.brehmer@ufsc.br \\ 2 Ph.D. in Nursing. Professor, Departamento de Enfermagem and the Programa de Pós-Graduação em Enfermagem in UFSC, CNPq \\ Researcher. Florianópolis, Santa Catarina, Brasil. E-mail: flavia.ramos@ufsc.br
}

\begin{abstract}
Objective: to analyze the perceptions of professors, students and service professionals of primary health care, regarding their experiences in the Reorientation Program for Professional Training in Health in the Nursing Courses.

Method: this is a qualitative research, in the form of a case study. The scenarios consisted of five nursing courses in higher education institutions, in the state of Santa Catarina. Twenty-two teachers and fourteen Primary Health Care professionals were interviewed. In order to understand the students' perception five focus groups were developed.

Results: are presented from three general categories called: Pró-Saúde: evaluations about the experiences, Pró-Saúde - considerations about the advances and Pró-Saúde - considerations about the challenges.

Conclusion: there are positive advances motivated by the Program throughout a contextual movement by an articulated, reflexive and critical training to the reality of health. However, there are challenges to reduce the gaps between services and training objectives.

DESCRIPTORS: Nursing education research. Education, nursing, diploma programs. Nursing. Education nursing. Nursing staff.

\section{EXPERIÊNCIAS DO PROGRAMA DE REORIENTAÇÃO DA FORMAÇÃO PROFISSIONAL NA ENFERMAGEM - AVANÇOS E DESAFIOS}

\section{RESUMO}

Objetivo: analisar a percepção de docentes, alunos e profissionais dos serviços de atenção primária à saúde acerca de suas experiências em projetos do Programa de Reorientação da Formação em Saúde nos Cursos de Enfermagem.

Método: trata-se de um estudo qualitativo, tipo estudo de caso. Os cenários foram cinco cursos de enfermagem em Instituições de Ensino Superior no Estado de Santa Catarina, contempladas pelo Programa. Foram entrevistados 22 docentes e 14 profissionais dos serviços. Para conhecer a percepção dos alunos foram realizados cinco grupos focais.

Resultados: apresentados segundo três categorias gerais, denominadas: Pró-Saúde: avaliações das experiências; Pró-Saúde - considerações sobre os avanços; e Pró-Saúde - considerações sobre os desafios.

Conclusão: há avanços motivados pelo Programa e pelo movimento contextual por uma formação crítica, reflexiva e articulada à realidade da saúde. Contudo, existem desafios para dirimir as lacunas entre os objetivos da formação e os objetivos dos serviços.

DESCRITORES: Pesquisa em educação de enfermagem. Programas de graduação em enfermagem. Enfermagem. Educação em enfermagem. Recursos humanos de enfermagem.

\section{EXPERIENCIAS DEL PROGRAMA DE REORIENTACIÓN DE LA FORMACIÓN PROFESIONAL EN ENFERMERÍA - AVANCES Y DESAFÍOS}

\section{RESUMEN}

Objetivo: analizar la percepción de docentes, alumnos y profesionales de los servicios de atención primaria para la salud, acerca de sus experiencias en el Programa de Reorientación de la Formación Profesional en la Salud, en los cursos de Enfermería.

Método: es un estudio cualitativo, tipo estudio de caso, teniendo como escenarios cinco cursos de enfermería en instituciones de enseñanza superior, en el estado de Santa Catarina. Fueron entrevistados 22 docentes y 14 profesionales de los servicios. Fueron realizados cinco grupos focales con los alumnos.

Resultados: son presentados a partir de tres categorías denominadas: Pró-Saúde: evaluaciones sobre las Experiencias; Pró-Saúde: consideraciones sobre los avances y Pró-Saúde: consideraciones sobre los desafíos.

Conclusión: hay avances motivados por el Programa y para una formación crítica, reflexiva y articulada para la realidad de la salud. Sin embargo, todavía existen desafíos para dirimir las lagunas entre los objetivos de la formación y de los servicios.

DESCRIPTORES: Investigación en educación de enfermería. Programas de graduación en enfermería. Enfermería. Educación en enfermería. Personal de enfermería. 


\section{INTRODUCTION}

The ordination of human resources training in the area of Health in Brazil, composes the competency role of the Unified Health System (SUS). This proposal emerged from the debates of the Movimento pela Reforma Sanitária, transitioned between the recommendations of the Final Report of the VIII National Health Conference (1986), which was incorporated into the Federal Constitution of 1988 and finally was expressed in the Organic Health Law 8,080, 1990 , which regulated the constitutional principles. ${ }^{1-3}$

Since the mid-1990s Nursing has acted as a pioneer, promoting changes in the process of professional training. Nursing has participated, in particular, with proposals from the Brazilian Nursing Association (Associação Brasileira de enfermagem$A B E n)$, through regional and national seminars in nursing higher education.

A milestone towards changes in the Brazilian health education is represented by the approval of the National Curricular Guidelines for undergraduate courses between 2001 and 2004. The curriculum revision was oriented towards training in line with the prerogatives and needs of the health system. The strengthening of the actions of the primary care level is a pressing but complex challenge that requires paradigm change. Health education, from the outset, connected to primary care, from the perspective of this model is potentially capable of effectively coining a thought and action in health.

Inspired with the challenge of promoting transformations in health education, the Brazilian government, through the Ministries of Education and Health, started to promote policies and programs with this aim in mind. The initiatives of the health sector represented concrete conditions, involvement of people and the availability of resources to enable proposals for the reorganization of health courses. They also stimulated critical thinking and had a positive impact on the transformations of the training process, with the mobilization and connecting of institutions and people in teaching and the health service. ${ }^{4-5}$

Different programs were launched, whose purposes in general, were to transform the training process in the area of health. One can cite such experiences as the Programa de Incentivo às mudanças Curriculares das Escalas Médicas (Promed), Vivências e Estágios na Realidade do Sistema Único de Saúde (VERSUS), Programa de Educação pelo Trabalho para a Saúde (PET-Saúde). However, one of the governmental initiatives launched in 2005, the National Program of Reorientation of Vocational Training (Programa Nacional de Reorientação da Formação em Saúde - Pró-Saúde), is an object for which one sought to look within this study. The purpose of Pró-Saúde was to promote curricular changes and strengthen teaching-service integration. ${ }^{6-7}$

Therefore, this study is confined to this universe of transformations in the areas of education and health. Its objective was to analyze the perception of teachers, students and professionals of primary health care services regarding their experiences in Pró-Saude projects in nursing courses.

Considering the limitations of a study of this nature, it is hoped to contribute with a debate relating to the theme, especially for the reflection-actionreflection process in nursing and health courses.

The presented indications value the concrete experiences and their protagonists, allowing to promote the advancement of projects which stimulate the changes, as well as for future interventions.

\section{METHOD}

A study with qualitative approach, which adopted the references of a case study. In case studies, the researcher's desire is to understand, in depth, a complex social phenomenon in its real context. ${ }^{8}$ Each location where the research was developed represented a case. Five nursing courses were studied in five higher education institutions in Santa Catarina, a State in the Southern Region of Brazil. The choice of these cases occurred due to the common characteristic among the institutions contemplated by the Pró-Saúde directive, whose projects were developed between the years 2005 and 2011.

Twenty-two teachers and 14 professionals from Primary Health Care services were interviewed through a semi-structured script. The sample was non-probabilistic. The coordinator of each project was the key subject and recommended the others, considering their involvement with the projects.

To understand the students' perception, five focal groups were held, one in each case. We invited the students of the last period of the course, who were on familiar terms during all their training in the development of Pró-Saude projects. There was an average participation of 13 students per focus group.

The data analysis process occurred simultaneously with collection followed by two basic steps: 1) data coding: designation of relevant concepts to answer the objectives of the study; 2) the establishment of analytical categories: extraction of concepts grouped by similarity and according to the possibility of a theoretical meaning being assigned. The theoretical framework to support the analysis was 
drawn from legal and theoretical sources regarding the curriculum of nursing undergraduate courses, the Pró-Saúde Program and SUS framework. The analysis was traditionally composed of categories in discourse texts and diagrams. The data were organized and categorized with the aid of Atlas.Ti software following the analysis process described.

The project was approved by the Committee of Ethics and Research with Human Beings (CEPSH) from the educational institution of origin and received protocol number 1801/2011. All participants signed the Informed Consent Form, as recommended by Resolution N. 466/2012 of the National Health Council.

The anonymity of the subjects and the preservation of the identification of the cases was one of the assumed commitments. Thus, for the presenta- tion information fragments, codes with the following characteristics were used: GF for focus groups (GF1 to GF5), D for professors (D1 to D22) and PS for service professionals (PS1 to PS14).

The construction of the categories obeyed the coincidence of codes generated in Atlas. Ti in all cases. Thus, three main categories and corresponding subcategories were defined that cover subjects' perspectives in a coincident way in all the studied contexts.

\section{RESULTS}

In order to understand the perspective of professors, students and primary care professionals regarding their experiences in the development of the Pró-Saúde projects, data analysis revealed three major categories with their respective sub-categories, which are presented in schematic form in Figure 1.

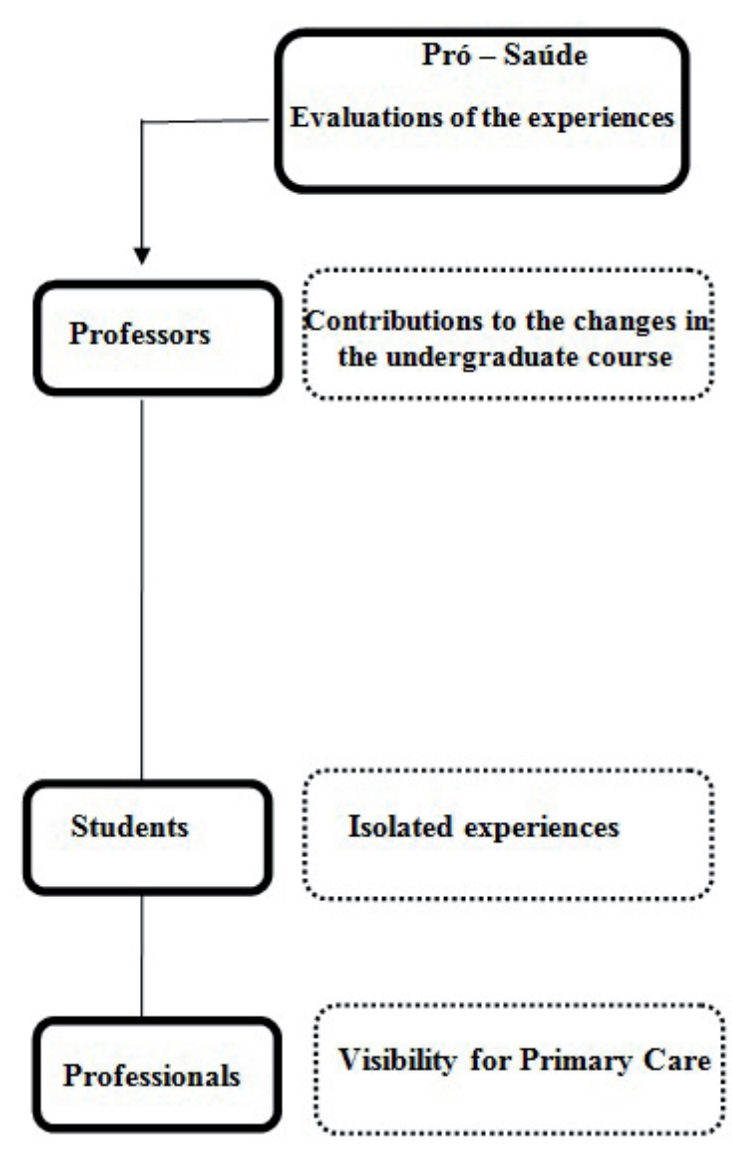

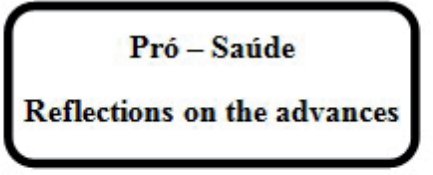

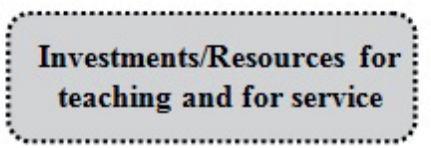

Promotion of teachingservice integration

Promotion of Permanent Education
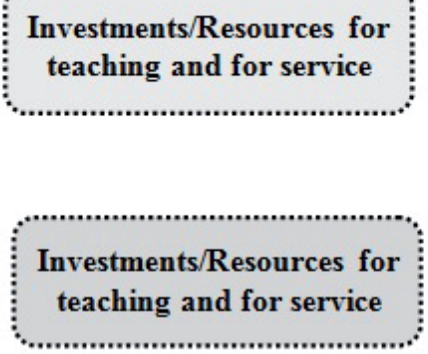

Promotion of teachingservice integration

Promotion of Permanent Education
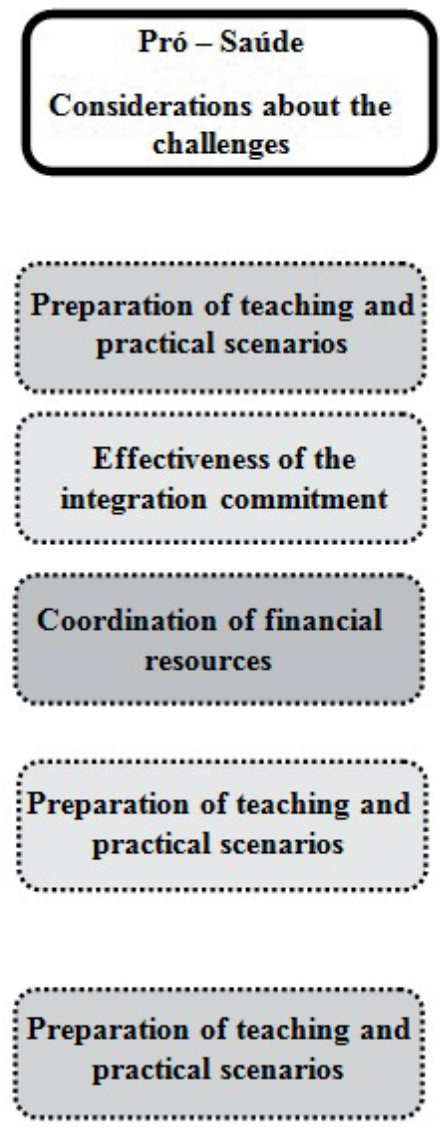

Effectiveness of the integration commitment

Coordination of financial resources

Figure 1 - Analysis categories and subcategories 
The first category was called Pró-Saúde: evaluations of the experiences. Teachers related Pró-Saude to the process of change in nursing courses initiated prior to the program, based on the National Curricular Guidelines. They saw the program in the way it was conceived, i.e. as a strategy to promote and stimulate curricular changes. Through the projects, the movement of the changes received feasible elements that were defined in the form of goals to be reached, in order to correspond to the agreed commitments. Pro-Saúde has added dynamism and concreteness to the processes of reformulation of pedagogical and curricular political plans, as well as to the organization and development of practices in health services.

[...] Pró-Saúde comes from within a movement, sometimes it is difficult to separate, many of the things that we put into our project were strategies, initiatives that we had already been creating to start this process [...] (D7).

For the students, Pró-Saúde, from the understanding of the conception of the program, through the construction of the project adjusted the realities of the courses, and up until the conduct of the actions, it did not give visibility. In the experience of the students of all the courses, Pró-Saúde was strongly related to some actions and / or specific activities.

[...] I did not have much knowledge about what Pró-Saúde was, how it worked, I just heard it said: 'PróSaúde supported this event, financed such project' [GF5].

The experiences of the professionals could be synthesized in a unique perception: that of associating the actions of the program with the promotion of primary health care.

[...] I think it tries to get closer to primary care. We can do a lot of interesting work, have a very rich experience [...] (PS5).

In the second general category, titled PróSaúde: reflections on the advances, perspectives emerged in relation to the advances coming from the development of the Pró-Saude projects.

The first subcategory, related to the contribution, was a point of unanimity among the subjects and related to the financial subsidy of the program. Investments were made in infrastructure for courses and units, consultancy, research development and participation in scientific events.

[...] there was a computer that we could use, so it ended up opening doors for us because some university resources had been applied there, so at times it made it easier to enter those places [GF4].
It improved the situation because it provided more resources, it allowed the purchase of materials to make diagnoses in the community, to buy material [...] (D11).

Pró-Saúde is a very valuable thing. We have material inside the clinic today because of Pró-Saúde (PS8).

Another contribution which Pró-Saúde brought, from the perspective of teachers and professionals, was the promotion of teaching-service integration. The interinstitutional ties were narrowed, and a greater number of process actors joined and participated in the planning, execution, follow-up and evaluation of teaching-service integration activities.

We have had many gains, because we have been able to broaden the discussions, bring the network into the academy, bring those professionals, and involve them in training [...] (D6).

[...] it has brought the service of the university closer, and this approach is vital. It already existed, but after, this relationship was strengthened in an academic, institutionalized way (PS2).

Also in the perception of teachers and professionals, another advance was the promotion of lifelong education. Activities in this sense occurred in the areas of universities and health units.

[...] we are using Pró-Saude money to create this permanent education, which is the training of the university professionals which we also call the service professional [...] (D21).

If it is fundamental for the university to be in the place of the service in order to train the professionals, today, it is fundamental for the service to be in the academic environment, in this intense movement of integration, because we realize that we are growing as a service, we are doing a master's degree, we are writing articles (PS4).

It was the reflections on the challenges to be overcome in the process of developing the Pró-Saúde actions that formed the third category, Pró-Saúde: considerations regarding the challenges, and their respective subcategories.

The perception of all subjects coincided with the preparation of the practice scenarios as an issue that still requires more attention and constitutes a challenge to reach the objective-images.

$[. .$.$] if the units were prepared before we arrived,$ the reception could be better. Sometimes we come and the person in the unit doesn't even attend us [...] (GF3).

[...] it is fundamental that they allow time for service, talk about cases, to release rooms, procedures, everything [...] (D4).

We have more problems in adjusting the schedules and the number of students that come. (PS6). 
In the context of the consolidation of the commitments of the teaching-service integration, teachers and professionals questioned the need to put this relationship into effect.

We have challenges, one of them I think is that the service and the professionals feel committed to the training of both the undergraduate and the individual (D8).

So there is this space for dialogue, I think we have made great strides in this period, but we still have a lot of progress to make, because it's not all the professionals who have this understanding, this availability, nor are all the teachers who have this understanding and willingness accept the opinion of others [...] (PS14).

Also from the teachers and professionals perspective, financial resources, considered as a contribution, were a cause of some discontent and presented a challenge to be overcome.

[...] we have some issues regarding resources, for example, there are specific dates to send the requests and sometimes we need the resources before, we have to develop some activity, so the university pays and only receives the money back after [...] (D9).

We received this furniture, but I think that money and the purchase of materials, this could be discussed more in the health center. The equipment arrived, but it didn't come to the health center which it was requested for [...]. I think this was a flaw, the need for the equipment should be discussed in the health center (PS11).

\section{DISCUSSION}

We cite the fact that the study was applied to five nursing professional training scenarios, so that the results evidenced the advances and challenges in the implementation and development of Pró-Saúde projects in the experiences studied as limitations of this study alone.

In the context of universities and courses, specifically in the health area, programs such as PróSaúde represent an important strategy, in addition to all the efforts made in the political-pedagogical and curricular reorganization movement.

Despite the limits of the method, this study aimed to contribute to the discussion of strategies incorporated into the professional training process. In the teaching and professional nursing teaching practices, the findings of this research can subsidize the construction of a body of knowledge in relation to the reorientation of the educational model together with the objectives as a critical, reflexive formation, and included and connected to the health needs of the population
The idea of a program such as Pró-Saúde was born from previous experiences of teaching-service integration and assessment of the adherence of undergraduate courses in the National Curricular Guidelines - especially from the realization that implementation of the guidelines in practice was still short of what was desired. Thus, the program has played an important role in the implementation of National Curricular Guidelines in healthcare courses. ${ }^{9}$

Pró-Saúde has made every effort to make changes to the curriculum matrix and has joined the movement to transform human resources training for the healthcare area. ${ }^{10}$

The awareness of Pró-Saúde as an aggregating element for the training experiences was the essential perception among the teachers of the nursing courses in this study.

Programs of this nature strengthen beyond training, as they have repercussions in the social sphere of higher education and care based on the real needs of the community, and promote the link between university, services and the user population. ${ }^{11-12}$

The inclusion of training into real care settings and nursing and health work contributes substantially to the changes in the graduation process, surpassing the walls of the academy and going against the real context, where stories of life and health care intertwine. Therefore, it is necessary to work in a critical and reflexive perspective, which promotes significant connections between practice and learning. Teachers have a strong role and a commitment to stimulate and lead the practical experiences of training to raise awareness among students about the determination of the health-disease process. The reflection of this movement will have an effect on working professionals to face the health needs of the population.

For primary health care, programs of this type serve to leverage this level of attention in a direction opposite to that of the forces of the clinical, technical, and curative model. ${ }^{14}$

Primary health care providers observed greater transparency of this scenario in the training process, especially since it can be accompanied from the beginning to the end. The meetings, from the beginning of the training, between the student and the reality of health services in the SUS, promote primary health care. ${ }^{15-17}$

Practical experiences in the world of work during nursing training are recognized as potential 
to influence the future of the profession, especially in the process of Primary Care consolidation. It is believed that, as reported in other countries, in Brazil the potential of experiences in services can be evidenced for the consolidation of professional competencies. ${ }^{18}$

The financial incentive of Pró-Saúde stood out as a contribution to the experiences of all the actors in this study, as it represents an opportunity for the purchase of equipment for the courses and for health units.

Institutions often coexist with the shortage or scarcity of resources which are needed to purchase more equipment. In units with more people involved which seek to innovate activities, there is a greater expenditure of materials or demand for other types of acquisitions. In this way, being able to allocate resources for these purposes facilitates the process in terms of financing. ${ }^{10,19}$

For the teachers and professionals of the services that participated in this study, the opportunity to develop Pró-Saúde projects brought contributions to their ongoing education processes.

Permanent health education is associated as one of the structuring elements of Pró-Saúde projects. In some program experiences, such initiatives still present challenges. However, there is no doubt about its transformative potential of teaching practices, health care with the continuous improvement of the service to the users, as well as the relationship between these scopes. ${ }^{15,20-21}$

Pró-Saúde has tightened the partnership relations between the higher education institution, professionals and health management, and SUS users, in the pursuit of common goals. The program institutionalized the relationships, in the sense of the formalization of the objectives. It started as a simple agreement for the use of the spaces of health units to a plan which connects knowledge and actions, and defines shared interests between the needs of teaching and service. ${ }^{15,22}$

Although studies such as this point to the promotion of teaching-service integration as a contribution of Pró-Saúde, the concreteness of these relationships still present weak points. In a relational context, such fragilities are detected, with emphasis on the relationship between the teaching actors and the service actors. In a way, this relationship is characterized by the passivity of the service professionals in accepting the proposals of work given by the universities. This fact corroborates the perpetuation of the vertical nature of the negotiations between academia and services, starting with planning in the university until the implementation of the actions, in the day to day of the units, in a solid association between the objectives of learning with the necessities of the services and of the attached population. ${ }^{18,22}$

It is not enough to transfer the teaching environment to the health care services network. Negotiations for the definition of common goals are implicit in this process and the meaning of the word "integrate" must go beyond the simple action of the academy occupying the space of the service. The process is complex and requires changes in behavior and commitment to education and health. ${ }^{20,23-24}$

The integration of teaching and service and policies or programs that promote the development of a training process in health and for the health system responds to the social evolution of the profession. Health and education managers, as well as professors, students and the community are co-responsible and co-participants for the consolidation of curricula, interinstitutional partnerships and training to address the real needs of all involved. ${ }^{25}$

\section{CONCLUSION}

The actors of the professional graduation course revealed undeniable advances motivated by the Pró-Saúde projects, which promoted critical, reflexive and articulated formation to the health reality from the perspective of the teaching-service integration. However, there are still major challenges to be addressed in bridging gaps between training objectives and service objectives.

The construction of the categories revealed the students' specific perspective on their experiences with the Program. Differently, teachers and professionals covered other elements involved in the process, more than one subcategory emerged for each category.

The study sought to highlight the confluences and not the specificities of each context. It is considered important to recognize the possible particular influences of the different realities, that is, of each institution in its scenario, however the subjects' reports showed evidence of the approximation of the meanings of their experiences in the actions of Pró-Saúde.

Issues such as dialogue, lifelong education, affinity of interests and financial investments have been revealed as the key pieces for the increasingly conscious promotion of proposals for changes in health education with the integration of teaching and service. 
The challenges remain within the framework of an effective interinstitutional commitment between health and education. This commitment refers to the daily life of students and teachers in health services, beyond the documentary formalities established in the agreements. It concerns the articulation of objectives and the true integration between the demands and expectations of teaching and health institutions.

\section{REFERENCES}

1. Ministério da Saúde (BR). Relatório Final da VIII Conferencia Nacional de Saúde. Relatório Final [Internet]. Brasília (DF): Conselho Nacional de Saúde; Ministério da Saúde; 1986 [cited 2014 Aug 13]. Available from: http://conselho.saude.gov.br/ biblioteca/Relatorios/relatorio_8.pdf

2. Brasil. Constituição da República Federativa do Brasil de 1988 [Internet]. Brasília (DF), 1988. [cited 2014 Aug 13]. Available from: http://www.senado.gov. br/legislacao/const/con1988/CON1988_05.10.1988/ CON1988.pdf

3. Brasil. Presidência da República. Casa Civil. Lei Orgânica da Saúde no .8 .080 de 19 de setembro de 1990. Dispõe sobre as condições para a promoção, proteção e recuperação da saúde, a organização e o funcionamento dos serviços correspondentes e dá outras providências [Internet]. Brasília (DF), 1990 [cited 2014 Aug 13]. Available from: http://www. planalto.gov.br/ccivil_03/leis/L8080.htm

4. Feuerwerker LCM, Ceccim RB. O quadrilátero da formação para a área da saúde: ensino, gestão, atenção e controle social. Physis [Internet]. 2004 [cited 2014 Aug 13]; 14(1):41-65. Available from: http://www. scielo.br/pdf/physis/v14n1/v14n1a04.pdf

5. Oliveira NA, Meirelles, RMS, Cury GC, Alves LA. Mudanças curriculares no ensino médico brasileiro: um debate crucial no contexto do Promed. Rev Bras Educ Med [Internet]. 2008 [cited 2014 Aug 13]; 32(3):33346. Available from: http://www.scielo.br/scielo. php?pid $=$ S0100-55022008000300008\&script $=$ sci $_{-}$ arttext

6. Brasil. Portaria Interministerial n. 2.101 de 3 denovembro de 2005. Institui o Programa Nacional de Reorientação da Formação Profissional em Saúde - PRÓ-SAÚDE para os cursos de graduação em Medicina, Enfermagem e Odontologia. Brasília (DF) [Internet], 2005 [cited 2014 Aug 13]. Available from: http:// portal.saude.gov.br/ portal/arquivos/pdf/2101.pdf

7. Ministério da Saúde (BR). Secretaria de Gestão do Trabalho e da Educação na Saúde. Secretaria de Gestão do Trabalho e da Educação na Saúde: SGETS: políticas e ações. Brasília (DF): Ministério da Saúde; 2012.

8. Yin RK. Estudo de caso: planejamento e métodos. $4^{\mathrm{a}}$. ed. Porto Alegre: Bookmann; 2010.
9. Haddad AE, Brenelli SL, Cury GC, Puccini RF, Martins MA, Ferreira JR, et al. Pró-Saúde e Pet-Saúde: a construção da política brasileira de reorientação da formação profissional em saúde. Rev Bras Educ Med [Internet]. 2012 [cited 2014 Aug 13]; 36(1, Suppl. 1):34. Available from: http://www.scielo.br/pdf/rbem/ v36n1s1/v36n1s1a01.pdf

10. Palmier AC, Amaral, JHL, Wernekc MAF, Senna MIB, Lucas SD. Inserção do aluno de odontologia no SUS: contribuições do Pró-Saúde. Rev Bras Educ Med [Internet]. 2012 [cited 2014 Aug 13]; 36(1, Suppl. 2):152-7. Available from: http:/ / revabeno.emnuvens. com.br/revabeno/article/viewFile/35/35

11. Tee S, Böckle E. 'Closing the gap'-a partnership approach to community care education for long term conditions. Nurs Educ Today. 2012; 32(7):822-8.

12. Scott $S$. 'New professionalism'- shifting relationships between nursing education and nursing practice. Nurs Educ Today. 2007; 28(2):240-5.

13. Schmidt NA, Brown JM. Service learning in undergraduate nursing education: strategies to facilitate meaningful reflection. J. Prof. Nurs [Internet]. 2015 [cited 2015 Nov 16]; In Press Available from: http://www.sciencedirect.com/science/article/pii/ S8755722315000794

14. Reibnitz KS, Daussy MFS, Silva CAJ, Reibnitz MT, KlohD. Rede Docente Assistencial UFSC/SMS de Florianópolis: reflexos da implantação dos projetos Pró-Saúde I e II. Rev Bras Educ Med [Internet]. 2012 [cited 2014 Aug 13];36(1, Suppl. 2):68-75. Available from: http:/ / www.scielo.br/ pdf/rbem/v36n1s2/a11v36n1s2.pdf

15. Almeida MM, Morais RP, Guimarães DF, Machado MFAS, Diniz RCM, Nuto SAS. Da teoria à prática da interdisciplinaridade: a experiência do Pró-Saúde Unifor e seus nove cursos de graduação. Rev Bras Educ Med. 2012; 36(1 Suppl. 1):119-26.

16. Silva MAM, Amaral JHL, Senna MIB, Ferreira EF. OPróSaúde e o incentivo à inclusão de espaços diferenciados de aprendizagem nos cursos de odontologia no Brasil. Interface Comun Saúde Educ [Internet]. 2012 [cited 2014 Aug 13]; 16(42):707-17. Available from: http:/ / www.scielo.br/scielo.php?script=sci_ arttext\&pid=S1414-32832012000300010

17. Pereira JG, Fracolli LA. The contribution of the teaching-service integration to the implementation of the health surveillance model: educators' perspective. Rev Latino-Am Enfermagem [Internet]. 2009 [cited 2014 Aug 13]; 17(2):167-73. Available from: http:/ / www.scielo.br/scielo.php? script $=$ sci arttext\&pid=S0104-11692009000200005

18. Halcomb EJ, Peters K, McInnes S. Pratice nurse experiences of mentoring undergraduate nursing students in Australian general practice. Nurs Educ Today [Internet]. 2012 [cited 2015 Nov 16]; 32(5):5248. Available from: http://www.sciencedirect.com/ science/article/pii/S0260691711002115 
19. Morais FRR, Leite IDR, Oliveira LL, Verás RM. A reorientação do ensino e da prática de enfermagem: implantação do Pró-Saúde em Mossoró, Brasil. Rev Gaúch Enferm [Internet]. 2010 [cited 2014 Aug 13]; 31(3):442-9. Available from: http://www.scielo.br/ pdf/rgenf/v31n3/v31n3a06.pdf

20. Ferreira JBB, Forster AC, Santos JS. Reconfigurando a interação entre ensino, serviço e comunidade. Rev Bras Educ Med. 2012; 36(1 Suppl. 1):127-33.

21. Wilcock PM, Janes G, Chambers A. Health care improvement and continuing interprofessional education: continuing interprofessional development to improve patient outcomes. J Contin Educ Health Prof. 2009; 29(2):84-90.

22. Colliselli LA, Tombini LHT, Leba ME, Reibnitz KS. Estágio curricular supervisionado: diversificando cenários e fortalecendo a interação ensino-serviço. Rev Bras Enferm [Internet]. 2009 [cited 2014 Aug 13]; 62(6):932-7. Available from: http://www.redalyc. org/articulo.oa?id=267019596022
23. Morita MC, Kriger L, Gasparetto A, Tanaka EE, Higasi MS, Messas AE, et al. Projeto Pró-Saúde odontologia: relato das atividades iniciais em universidades do Estado do Paraná. Espaço Saúde [Internet]. 2007 [cited 2014 Aug 13]; 8(2):53-7. Available from: http:/ / www.ccs.uel.br/ espacoparasaude/v8n2/Relato\%20_v8\%20n2_.pdf

24. Andrade SR, Boehs AE, Mattia D, Boehs CGE, Daussy MFS. Cooperação e relacionamento entre instituições de ensino e serviço de saúde: o Pró-Saúde enfermagem. Texto Contexto Enferm [Internet]. 2014 [cited 2015 Jan 14]; 23(1):160-6. Available from: http:/ / www.scielo.br/pdf/tce/v23n1/pt_01040707-tce-23-01-00160.pdf

25. Forber J, DiGiacomo M, Davidson P, Carter B, Jackson D. The context, influences and challenges for undergraduate nurse clinical education: continuing the dialogue. Nurs Educ Today [Internet]. 2015 [cited 2015 Nov 16]; 35(2015):1114-8. Available from: http:/ / www.sciencedirect.com/science/article/pii/ S0260691715002762 